\title{
Microglial Activation in Stroke: Therapeutic Targets
}

\author{
Midori A. Yenari, Tiina M. Kauppinen, and Raymond A. Swanson \\ Department of Neurology, University of California San Francisco and San Francisco Veterans Affairs Medical Center, San \\ Francisco, California 94121
}

\begin{abstract}
Summary: Microglial activation is an early response to brain ischemia and many other stressors. Microglia continuously monitor and respond to changes in brain homeostasis and to specific signaling molecules expressed or released by neighboring cells. These signaling molecules, including ATP, glutamate, cytokines, prostaglandins, zinc, reactive oxygen species, and HSP60, may induce microglial proliferation and migration to the sites of injury. They also induce a nonspecific innate immune response that may exacerbate acute ischemic injury. This innate immune response includes release of reactive oxygen species, cytokines, and proteases. Microglial activation requires hours to days to fully develop, and thus presents a target for therapeutic intervention with
\end{abstract}

a much longer window of opportunity than acute neuroprotection. Effective agents are now available for blocking both microglial receptor activation and the microglia effector responses that drive the inflammatory response after stroke. Effective agents are also available for targeting the signal transduction mechanisms linking these events. However, the innate immune response can have beneficial as well deleterious effects on outcome after stoke, and a challenge will be to find ways to selectively suppress the deleterious effects of microglial activation after stroke without compromising neurovascular repair and remodeling. Key Words: NF- $\kappa$ B, AP-1, PARP-1, minocycline, inflammation, ischemia, TREM2.

\section{INTRODUCTION}

Stroke is a frequent cause of death and disability worldwide. In ischemic stroke, cessation of blood flow through a cerebral artery leads to energy depletion and subsequent death of cells in the ischemic territory. Both the ischemia per se and resulting cell death can induce an inflammatory response, which can in turn injure otherwise viable cells. ${ }^{1,2}$ The inflammatory response can also impair neurogenesis and other postischemic changes that are thought to contribute to functional recovery after stroke. $^{3-5}$ Several interventions have been shown to reduce acute ischemic cell death in animal models of stroke, ${ }^{6}$ but these are generally ineffective if not initiated very soon after onset of ischemia. These interventions have consequently been difficult to put into clinical practice, because the vast majority of stroke patients do not present for medical care until many hours after symptom onset. By contrast, brain inflammation develops over a much slower time course, and is thus more amenable to therapeutic intervention.

The innate immune response is a triggered by a variety

Address correspondence and reprint requests to: Raymond A. Swanson, M.D., (127) Neurology, VAMC, 4150 Clement St., San Francisco, CA 94121. E-mail: raymond.swanson@ucsf.edu. of signals that, unlike the adaptive immune response, do not require antibody recognition. Microglia are the resident macrophages in brain, and they play a critical role in the innate immune response. ${ }^{7-9}$ Microglia normally display an extremely ramified appearance, but when activated assume a more amoeboid morphology and express surface markers that make them virtually indistinguishable from macrophages and circulating monocytes. Microglial activation is the initial step in the CNS inflammatory response; depending on the stimulus, this step may be followed by infiltration of circulating monocytes, neutrophils, and T-cells, and by reactive astrocytosis. ${ }^{10}$ Microglial activation is not, however, a univalent state, and the morphological and gene expression changes associated with microglial activation vary enormously with the nature, strength, and duration of the stimulus. ${ }^{11}$ Moreover, evidence suggests that microglia populations in the brain are heterogeneous, and that these populations may respond differently to similar stimuli. ${ }^{12}$

This review focuses specifically on aspects of microglia that contribute to ischemic injury. It is important, however, to place this approach in context. Although there is now strong evidence that the inflammatory response can exacerbate ischemic injury, ${ }^{13-18}$ there is also evidence that some aspects of the inflammatory response are important for tissue repair. These aspects include 
phagocytosis of cell debris, remodeling of the extracellular matrix, and the release of cytokines and trophic factors. ${ }^{5,19,20}$ These beneficial aspects of the microglial response are beyond the scope of the present review, but they must be considered in contemplating the net effect of manipulations that influence microglial activation. Temporal factors may be particularly crucial in this respect, because some evidence suggests that the cytotoxic aspects of inflammation are most important in the first few days after stroke, and that the salutary effects become more important later on. ${ }^{5,20}$ An additional caveat is that microglia do not act in isolation, but rather in concert with infiltrating immune cells from the blood stream, astrocytes, and other cells of the brain parenchyma.
Thus, our focus here on microglia is primarily an organizational approach.

Factors influencing microglial contribution to ischemic injury may be divided into three components, in analogy to a reflex loop (FIG. 1). The first of these is an afferent limb, whereby microglia detect ischemic cell injury and related alterations in brain homeostasis; the second is a signal transduction limb, in which these signals are integrated and transduced into genomic or other signals; and the third is an effector limb, whereby microglia directly or indirectly contribute to bystander cell death. In this review we consider these components in reverse order, beginning with the efferent, cytotoxic limb.

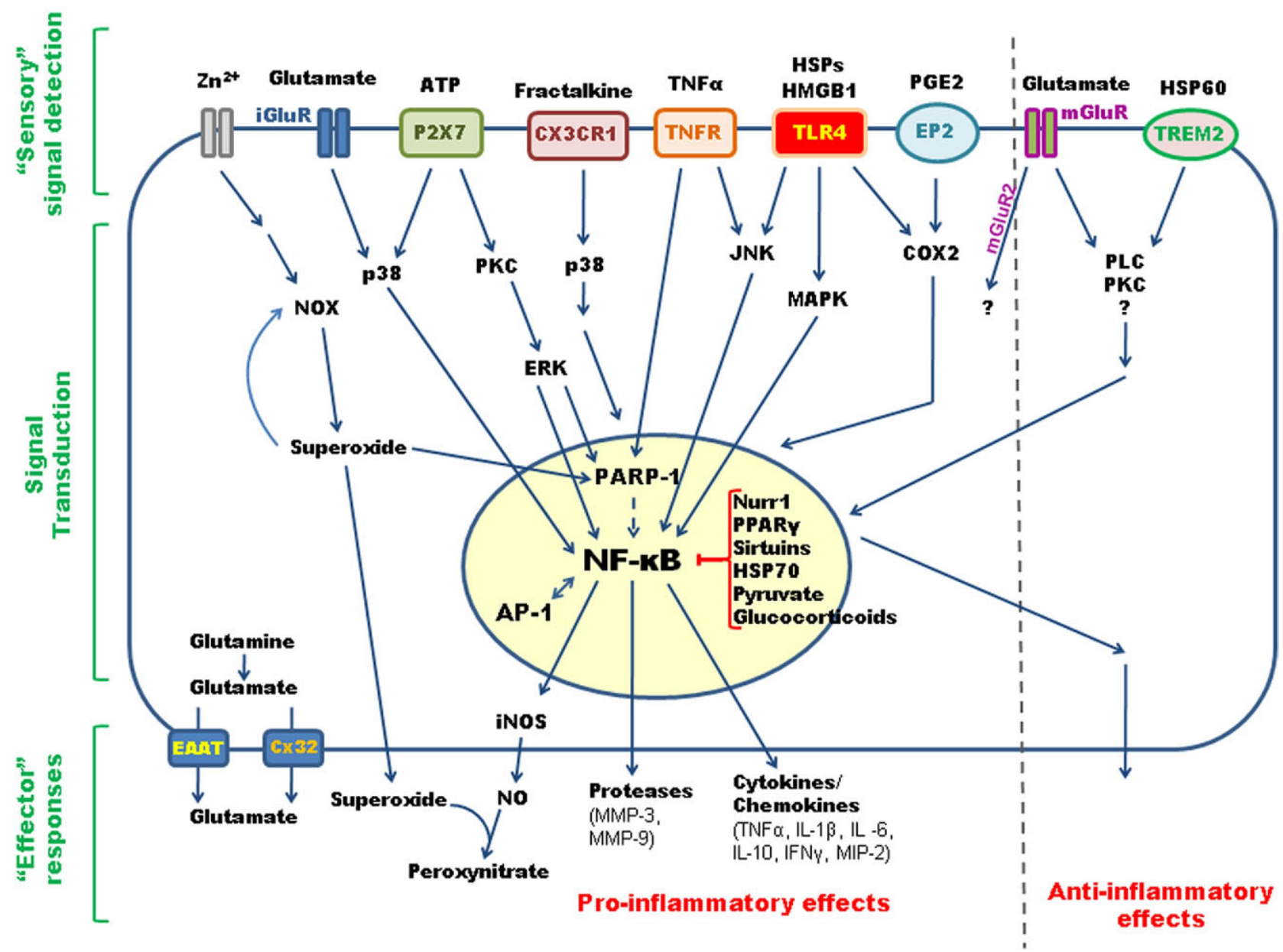

FIG. 1. Microglial responses to cerebral ischemia can be conceptualized in terms of three components: a sensory component, involving detection of extracellular signals by an array of cell-surface and intracellular receptors; a signal transduction component, whereby these signals influence gene expression in ways that are dependent on the intensity, duration, and types of signals detected; and an effector component, whereby numerous proinflammatory responses can be activated. For simplicity, many additional factors and interactions between factors are omitted here. AP-1 = transcription factor AP-1 (activator protein 1); COX2 = cyclooxygenase 2; Cx32 = connexin-32 (gap junction beta-1 protein); CX3R1 = fractalkine receptor; EAAT = excitatory amino acid transporter; EP2 = prostaglandin E2 receptor; ERK = extracellular signal-regulated kinase; HMGB1 = high-mobility group box 1; HSP = heat shock protein; iGluR = ionotropic glutamate receptor; IFN $\gamma=$ interferon $\gamma$; IL = interleukin; iNOS = inducible nitric oxide synthase; JNK = C-Jun N-terminal kinase; MAPK = mitogen-activated protein kinase; MIP = microtubule interacting protein; MMP = matrix metalloproteinase; mGluR = metabotropic glutamate receptor; $\mathrm{NF}-\kappa \mathrm{B}=$ nuclear factor $\kappa \mathrm{B} ; \mathrm{NO}=$ nitric oxide; $\mathrm{NOX}=\mathrm{NADPH}$ oxidase; $\mathrm{P}_{2} \mathrm{X}_{7}=\mathrm{P} 2 \mathrm{X}$ purinoreceptor 7; PARP-1 = poly(ADP-ribose) polymerase 1; PGE2 = prostaglandin E2; PKC = protein kinase C; PLC = phospholipase C; PPAR $\gamma=$ peroxisome proliferator activated receptor $\gamma$; TLR4 $=$ Toll-like receptor 4; TNF $\alpha=$ tumor necrosis factor $\alpha$; TNFR = tumor necrosis factor receptor; TREM2 = triggering receptor expressed on myeloid cells 2. 


\section{MECHANISMS OF MICROGLIAL CYTOTOXICITY IN ISCHEMIA}

Microglia, like macrophages, have a repertoire of responses that facilitate rapid sequestration and killing of invading microorganisms and limit the effects of trauma and cell necrosis. ${ }^{11}$ These responses include rapid migration, proliferation, and the release of superoxide, nitric oxide (NO), proteases, and cytokines. Some of these responses may be counterproductive after stroke and thus provide potential therapeutic targets.

\section{Superoxide production}

Superoxide is produced by the partial reduction of molecular oxygen to form $\mathrm{O}_{2}{ }^{\circ}$. Superoxide in turn reacts with other molecules to produce more highly reactive oxygen species, such as peroxynitrite, hypochlorous acid, carbonyl radical, and hydroxyl radical, all of which are directly cytotoxic to neurons and other cells. Superoxide and these other reactive species also promote microglial activation in a feed-forward manner. ${ }^{21,22}$ The production of superoxide by microglia occurs primarily by NADPH oxidase (NOX), of which several isoforms have been characterized. ${ }^{23,24}$ Of note, glucose availability can be rate-limiting for NADPH production, and thus for superoxide production, and this provides a mechanism by which hyperglycemia can exacerbate injury during ischemia or inflammation. ${ }^{25,26}$

Recent work has shown that microglia can potentiate injury to blood-brain barrier constituents (astrocytes and endothelial cells) via NOX-mediated superoxide in cell culture models of ischemia. ${ }^{13}$ In addition, several groups have shown that mice deficient in the gp91 subunit of NOX2 have smaller infarcts than do wild-type mice, ${ }^{27-29}$ and that outcomes from experimental cerebral ischemiareperfusion are improved with early administration of the pharmacological NOX inhibitors apocynin ${ }^{29-33}$ and honokiol. ${ }^{34,35}$ These results identify NOX as a promising target for therapeutic intervention, but it is possible that the efficacy of these treatment strategies may be due largely or in part to inhibition of NOX in cell types other than microglia. ${ }^{25}$ There are as yet no published studies addressing the efficacy of NOX inhibitors administered at delayed time points after ischemia, in a manner selectively targeting the inflammatory response.

\section{Nitric oxide}

Activated microglia produce NO by upregulating the expression of inducible nitric oxide synthase (iNOS). Brain ischemia causes an upregulation of iNOS and increased NO production. ${ }^{36,37}$ The cytotoxicity of NO is thought to be due primarily to its reactive metabolite, peroxynitrite, which is formed by reaction with superoxide. ${ }^{38}$ Pharmacological inhibition of iNOS with aminoguanidine reduces infarct volume in mice, ${ }^{37}$ and iNOSnull mice have smaller infarcts and better neurologic outcomes than wild-type control animals. ${ }^{39}$ Hypothermia after ischemia likewise reduces microglial iNOS expression and NO production. ${ }^{40}$ As with NOX inhibitors, however, iNOS inhibitors have not yet been evaluated for use at delayed time points after ischemia in a manner that would provide sustained suppression of inflammation-induced NO production.

\section{Matrix metalloproteinases}

Matrix metalloproteinases (MMPs) are proteases that can break down extracellular proteins, such as collagen, and are involved in extracellular matrix remodeling. Normally found in the cytosol in an inactivated state, MMPs are cleaved by proteases such as plasmin or other MMPs to their active state. ${ }^{41}$ Some MMPs, notably MMP-9, also have direct cytotoxic effects and can disrupt the blood-brain barrier. ${ }^{42}$ Microglia are the major source of MMP release following ischemia, especially MMP-3 and MMP-9. ${ }^{43,44}$

In experimental stroke models, acute MMP inhibition reduces infarct size, brain edema, and recombinant tissue plasminogen activator-induced hemorrhage, ${ }^{45}$ and mice deficient in MMP-9 or MMP-3 have reduced ischemic injury relative to wild-type controls. ${ }^{46,47}$ However, prolonged inhibition of MMPs after ischemia may have deleterious effects on functional recovery, because these proteases are important in neurovascular remodeling after stroke. ${ }^{20}$ Minocycline protects against permanent cerebral ischemia in wild-type but not in MMP-9-deficient mice, suggesting this as a mechanism by which minocycline exerts its neuroprotective effect. ${ }^{48}$ Doxycycline also suppresses postischemic MMP-9 activity, ${ }^{49}$ and both direct and indirect pathways for MMP-9 inhibition by minocycline and doxycycline have been described. ${ }^{50,51}$

\section{Glutamate}

Microglia can release glutamate through hemichannels, by reversal of glutamate uptake, and by upregulating glutaminase. ${ }^{52}$ This release can produce neuronal death in culture and in ex vivo slice preparations. ${ }^{52,53}$ Glutamate release from microglia might thus contribute to ischemic brain injury, ${ }^{54}$ but the effect of glutamate release from microglia is likely to be small relative to the effects of neuronal glutamate release and failure of astrocyte glutamate reuptake that occur during brain ischemia. Nonetheless, glutamate release from chronically activated microglia in the postischemic period could contribute to delayed neuronal death at infarct margins or after transient ischemia. Microglia can also take up glutamate, ${ }^{55}$ but the net effect of this uptake relative to rapid, high-capacity astrocyte uptake is unknown.

\section{Chemokines, cytokines, and trophic factors}

Resting microglia release a variety of chemokines and cytokines, and the pattern of this release is dramatically 
altered after ischemia. ${ }^{56}$ These factors function primarily as intercellular signaling molecules, and many have feedforward effects in driving the inflammatory response. Some, such as tumor necrosis factor $\alpha(\mathrm{TNF} \alpha)$, can also have direct cytotoxic effects ${ }^{57}$ and promote disruption of the blood-brain barrier. ${ }^{58}$ Microglia also release a number of neurotrophic factors, and there is evidence that trophic factors released from microglia are important in maintaining neuronal integrity after an ischemic insult. ${ }^{59-61}$ These observations highlight the complexity of the microglial innate immune response and the potential problems inherent in unselective inhibition of this response.

\section{SIGNALING PATHWAYS DRIVING MICROGLIAL ACTIVATION IN ISCHEMIA}

Microglia continuously monitor the extracellular space and adjacent cell surfaces for evidence of homeostatic perturbations. Almost any change in these is capable of inducing microglial activation, but certain factors appear to be of salient importance in ischemia and have discrete signaling pathways.

\section{Purinergic receptors}

Purinergic receptors have emerged as key sensors of brain injury. Of the numerous purinergic receptors identified, $\mathrm{P} 2 \mathrm{X}_{7}$ and $\mathrm{P} 2 \mathrm{Y}_{12}$ have been best characterized in this respect, but $\mathrm{P}_{2} \mathrm{X}_{4}$ and adenosine receptors also contribute. ${ }^{62}$ The $\mathrm{P} 2 \mathrm{X}_{7}$ receptors are expressed by resting microglia, and this expression is upregulated after brain injury. ${ }^{63}$ Activation of $\mathrm{P} 2 \mathrm{X}_{7}$ receptors triggers microglia proliferation ${ }^{64,65}$ superoxide production,${ }^{66}$ release of interleukin $1 \beta$ (IL- $1 \beta),{ }^{67,68}$ and release of $\mathrm{TNF} \alpha{ }^{64,69}$ However, microglia also exhibit reduced phagocytosis during $\mathrm{P} 2 \mathrm{X}_{7}$ receptor stimulation. ${ }^{70}$ Activation of microglial $\mathrm{P}_{2} \mathrm{Y}_{12}$ receptors leads to process extension and subsequent microglia migration toward the stimulus source through interactions with integrin- $\beta 1$. $^{71,72}$

Both $\mathrm{P} 2 \mathrm{X}_{7}$ and $\mathrm{P} 2 \mathrm{X}_{12}$ receptors respond to ATP as an endogenous agonist. It has been postulated that ATP is released into the extracellular space as a result of tissue injury, but it is unlikely that this occurs simply as a passive result of membrane disruption. Ischemic injury, for example, produces energy failure and ATP depletion, and ATP released into brain extracellular space is quickly degraded by exonucleases. ${ }^{73}$ Thus, an active, ongoing release of ATP is more likely to be the stimulus source acting on microglial purinergic receptors. A feedforward, ATP-induced release of ATP from astrocytes is one possible mechanism. ${ }^{74}$

Experimental studies have shown that $\mathrm{P} 2 \mathrm{X}_{7}$ antagonists reduce injury and postinjury inflammation when administered acutely after spinal cord injury ${ }^{75}$ or stroke. ${ }^{76}$ However, there is also report of stroke exacer- bation by $\mathrm{P} 2 \mathrm{X}_{7}$ antagonists. ${ }^{77}$ These studies are intriguing, but their interpretation is complicated because these antagonists may also affect other purinergic receptors at the concentrations achieved in vivo, and cell types other than microglia express $\mathrm{P} 2 \mathrm{X}_{7}$ and other purinergic receptors.

\section{Toll-like receptors and high-mobility group box 1 protein}

Innate immune responses are frequently mediated by Toll-like receptors (TLRs), a family of transmembrane proteins involved in the recognition of and defense of microbials. Toll-like receptors are found on a several cell types in the CNS, including microglia. Microglia are activated following stimulation of TLR4, which in turn leads to the upregulation of several proinflammatory genes. Work in neonatal mice suggests that TLR4 is necessary for microglial activation following hypoxia/ ischemia, ${ }^{14}$ and several groups that have shown that TLR4-deficient mice have better neurological outcomes following experimental stroke. ${ }^{78-81}$

How TLRs are activated in stroke is not precisely known, but endogenous ligands include hyaluronic acid, fibronectin, heat shock proteins (HSP), and heparin sulfate. In stroke models, HSP60 has been shown to activate TLR4 and contribute to brain injury. ${ }^{82}$ Toll-like receptors have also been implicated in the phenomenon of tolerance, whereby stimulation of one or more of these receptors with ligands such as lipopolysaccharide (TLR4) or CpG (TLR9) led to protection from subsequent lethal insults. ${ }^{83-86}$ Mice lacking these receptors failed to achieve tolerance, ${ }^{83}$ but the role for microglia in this process remains to be established.

The high-mobility group box 1 (HMGB1) protein is another endogenous agonist at TLR2 and TLR4 receptors. HMGB1 is normally localized to the nucleus in all cells, where it functions as a nuclear protein involved in enhancing transcription. ${ }^{87}$ However, necrotic cell death induces active release of HMGB $1,{ }^{88,89}$ and antibody to HMGB1 reduces injury in experimental stroke. ${ }^{90}$

\section{Chemokine and cytokine receptors}

Chemokines are a family of regulatory polypeptides with roles in cellular communication and inflammatory cell recruitment. Fractalkine, a neuronally expressed chemokine, acts through its G-protein-coupled receptor CX3C. Following ischemia, its expression has been localized to viable neurons in the infarct periphery as well as some endothelial cells. ${ }^{91}$ Fractalkine is constitutively expressed in the CNS, mainly by neurons, and is upregulated and released in response to proinflammatory stimuli. ${ }^{92}$ Expression of the fractalkine receptor, CX3CR1, is observed only on microglia and macrophages, suggesting that fractalkine is involved in neuron-microglial signaling. ${ }^{91}$ Mice deficient in fractalkine ${ }^{93}$ or its microglial receptor ${ }^{94}$ have smaller infarct sizes and better functional 
outcomes. CX3CR1 antagonists are currently under development. $^{95,96}$

\section{Prostaglandin receptors and nonsteroidal anti-inflammatory drugs}

Prostaglandins (PGs) are potent autocrine and paracrine oxygenated lipid molecules. Prostaglandins, especially PGE2, contribute to cell injury in ischemia and in some neurodegenerative diseases. PGE2 signaling is mediated by interactions with four distinct $G$ protein-coupled receptors, EP1-EP4, which are differentially expressed on neuronal and glial cells throughout the CNS. Activation of EP2 has been shown to mediate microgliainduced paracrine neurotoxicity. ${ }^{97}$ There are currently no selective EP2 antagonists available, but the production of PGE2 can be inhibited by a variety of compounds such as aspirin and indomethacin, which are termed nonsteroidal anti-inflammatory drugs (NSAIDs). ${ }^{98}$ NSAIDs have been shown to suppress the effector molecules produced by lipopolysaccharide activation of microglia primary cultures. In addition, primary microglia cell cultures prepared from $\mathrm{EP}^{-/-}$mice exhibit reduced secretion of proinflammatory cytokines and chemokines. ${ }^{99}$ Thus, EP2 antagonists appear to be an attractive target for suppressing deleterious effects of inflammation after stroke. A complicating factor, however, is that antagonists at neuronal EP2 receptors can impair neuronal survival. ${ }^{98}$

\section{Glutamate receptors}

Microglia in culture express several subtypes of glutamate receptors, including subunits of the AMPA receptor, kainate receptor, and NMDA receptor. ${ }^{100-104}$ They also express all three groups of metabotropic receptors: group I (mGluR5), ${ }^{105}$ group II (mGluR2 and 3), ${ }^{106,107}$ and group III (mGluR4, 6, and 8). ${ }^{106,108}$ Stimulation with either glutamate or with ionotropic glutamate receptor agonists induces microglial proliferation, morphological changes characteristic of microglial activation, and release of IL- $1 \beta, \mathrm{TNF} \alpha$, NO, and ATP. ${ }^{100,101,104,109}$ Conversely, activation of most mGluR types inhibits microglial inflammatory responses, ${ }^{107,110-112}$ with the exception that mGluR2 activation promotes microglial neurotoxicity. ${ }^{106,107}$

Microglia expression of glutamate receptor subtypes in vivo has not been extensively characterized, but protein expression of mGluR1, mGLuR2/3, and mGluR8 has been reported in microglia surrounding human multiple sclerosis lesions, ${ }^{113}$ and expression of ionotropic glutamate receptors has been detected in reactive microglia in damaged areas of the hippocampus following ischemia. ${ }^{114}$ The acute administration of an mGluR5 agonist after experimental stroke or spinal cord injury is neuroprotective, ${ }^{115,116}$ and an mGluR5 agonist was also shown to reduce microglial activation in the spinal cord injury study, ${ }^{116}$ suggesting that the neuroprotective effect of these agents may be attributable to the suppression of microglial activation.

\section{TREM2}

TREM2 is a newly identified molecule involved in innate immunity. It was originally characterized by its ability to bind pathogens such as bacteria and initiate phagocytosis. ${ }^{117}$ It has been described on activated macrophages and microglia, ${ }^{118-120}$ and binds to one or more ill-defined ligands on eukaryotic cells including neurons and astrocytes. ${ }^{121-123}$ More recent work suggests that one such ligand might be HSP60, ${ }^{122}$ a mitochondrial stress protein that can move to the cell surface under appropriate conditions. ${ }^{124}$ Stimulation of HSP60 stimulates phagocytic activity of TREM2 expressing microglia, but not of TREM2 deficient microglia. ${ }^{122}$ When bound to a ligand, TREM2 engages its adapter protein, DAP12, which then recruits and activates the tyrosine kinase Syk, ${ }^{120,125,126}$ leading to downstream signaling through pathways including phosphatidylinositol 3-kinase (PI3K), phospholipase $\mathrm{C} \gamma 1$, and $\mathrm{p} 44-\mathrm{p} 42$ extracellular signal regulated kinase (ERK), but not through classical inflammatory pathways such as nuclear factor $\kappa \mathrm{B}(\mathrm{NF}-\kappa \mathrm{B})$ and the p38 stress-activated protein kinase. ${ }^{127,128}$

TREM2 has been shown to mediate phagocytosis of apoptotic neurons. ${ }^{121}$ TREM2 binding activates microglia to phagocytose injured cells without stimulating a typical inflammatory response or the release of reactive oxygen species. Conversely, loss of TREM2 impairs phagocytosis and promotes inflammation. ${ }^{119}$ Blockade of TREM2 using a monoclonal antibody in experimental autoimmune encephalomyelitis led to exacerbation of immune responses with increased demyelination and worsened neurological function. ${ }^{129}$ Although it has not yet been reported in brain ischemia models, these findings suggest that TREM2 may similarly regulate microglial phagocytosis and inflammatory responses in postischemic brain.

\section{Zinc}

Zinc is involved in the pathogenesis of several diseases affecting the CNS. ${ }^{130}$ In mammalian brain, zinc is concentrated in the presynaptic vesicles of a subset of glutamatergic axon terminals. ${ }^{131}$ These axon terminals are distributed throughout the forebrain, and are particularly dense in hippocampus and in cerebral cortex. ${ }^{132,133} \mathrm{Ve}-$ sicular zinc is released into the extracellular space in a calcium-dependent manner during normal neuronal activity, ${ }^{134,135}$ and is massively released, along with protein-bound zinc, in many pathological conditions. ${ }^{130,136}$ Treatment with zinc chelators has been shown to reduce neuronal death in animal models of cerebral ischemia, trauma, hypoglycemia, and neurodegenerative disorders. ${ }^{137-142}$ These effects may be due in part to suppression of zinc-mediated microglial activation. Zinc has 
been shown to induce activation of microglia in culture and in brain, and injection of the zinc chelator CaEDTA prevents ischemia-induced microglial activation. ${ }^{22}$ The mechanism of this effect appears linked to the more general effect of oxidant stress on microglial and macrophage activation. ${ }^{21}$ Zinc has been shown to upregulate NADPH oxidase in these cells, and the effect of zinc on microglial activation is blocked in the absence of NADPH oxidase activity. ${ }^{22}$ The effect of zinc is also blocked by inhibiting activation of poly(ADP-ribose) polymerase 1 (PARP-1) or translocation of NF- $\kappa \mathrm{B}$ translocation, thus linking the zinc effect to established pathways of microglial activation. ${ }^{22}$

\section{SIGNAL TRANSDUCTION EVENTS LINKING STIMULI TO MICROGLIAL ACTIVATION}

Microglia responses to activating stimuli are modulated by the type, intensity, duration, and combination of stimuli present. ${ }^{11}$ These factors are integrated through several signal transduction pathways to influence changes in gene expression. Interventions that block these signal transduction pathways are among the most effective agents available for suppressing microglial activation. Microglial activation is undoubtedly also influenced by one or more processes other than altered gene expression, but much less is presently known about these pathways in the setting of brain ischemia.

\section{Mitogen-activated protein kinase (MAPK) cascade}

Mitogen-activated protein kinases play an important role in transducing stress-related signals through a cascade of intracellular kinase phosphorylation and transcription factor activation. ${ }^{143,144}$ Three interlinked signaling pathways are activated by cerebral ischemia: the stress-activated protein kinases/c-Jun N-terminal kinases (SAPK/JNK), the p38 MAPKs, and the extracellular signal-regulated kinases (ERKs). ${ }^{144-146}$ All three of these pathways have been described in activated immune cells, including microglia. p38 MAPK promotes the stabilization and enhanced translation of mRNAs encoding proinflammatory proteins. ${ }^{147}$ Activated (phosphorylated) p38 has been demonstrated in microglia in animal models of brain ischemia, ${ }^{146,148,149}$ and pharmacological inhibition of p38 with the compound SD-282 decreased the number of activated microglia in ischemic brain. ${ }^{150}$ The MAPK/ ERK signaling pathway may also regulate inflammation through its effects on PARP-1 activation, which (as detailed later in this review) is an important modulator of proinflammatory gene expression. ${ }^{151}$ Pharmacological inhibition of both the $\mathrm{p} 38^{152,153}$ and the MAPK/ERK ${ }^{154}$ signaling pathways improves outcomes in a mouse model of ischemia-reperfusion, but the extent to which these effects are due to reduced inflammation has not been established.

\section{NF- $\kappa B$ and AP-1}

$\mathrm{NF}-\kappa \mathrm{B}$ is a dimeric transcription factor consisting of subunits of the Rel family. ${ }^{155}$ The most common form of $\mathrm{NF}-\kappa \mathrm{B}$ is a heterodimer composed of Rel A (p65) and $\mathrm{p} 50$. NF- $\kappa \mathrm{B}$ is normally located in the cytoplasm bound to its endogenous inhibitor protein, known as $\mathrm{I} \kappa \mathrm{B}$. Phosphorylation of $\mathrm{I} \kappa \mathrm{B}$ by $\mathrm{I} \kappa \mathrm{B}$ kinase (IKK) leads to $\mathrm{I} \kappa \mathrm{B}$ phosphorylation, ubiquitination, and degradation. This liberates NF- $\kappa \mathrm{B}$ and allows it to translocate to the nucleus, where it binds to specific domains (the $\kappa \mathrm{B}$ domains) of gene promoter regions. Many genes involved in inflammation contain functional $\kappa \mathrm{B}$ domains, including TNF- $\alpha$, intercellular adhesion molecule-1 (ICAM-1), cyclooxygenase-2 (COX-2), iNOS, and IL-6. ${ }^{155} \mathrm{NF}-\kappa \mathrm{B}$ also drives microglial morphological activation. ${ }^{22}$ Mice deficient in the NF- $\kappa \mathrm{B}$ p50 subunit have reduced brain injury after experimental stroke. ${ }^{156}$ Similar observations were made using deletion of the I $\kappa \mathrm{B}$ kinase. ${ }^{157}$ In global ischemia, neuronal damage was significantly attenuated by introducing NF- $\kappa \mathrm{B}$ decoy oligodeoxynucleotides into rat brain neurons through the carotid artery. ${ }^{158}$ Others, however, have observed deleterious effects of NF- $\kappa \mathrm{B}$ inhibition: constitutive activation of $\mathrm{I} \kappa \mathrm{B}$ kinase to promote nuclear translocation of NF- $\kappa \mathrm{B}$ increased infarct size ${ }^{157}$ and rats given diethyldithiocarbamate, an NF- $\kappa \mathrm{B}$ inhibitor, also had larger infarct size, compared with controls. ${ }^{159}$ The reasons for these discrepancies are not clear, but may stem from the fact that NF- $\kappa \mathrm{B}$ has prosurvival effects in neurons and other cell types. ${ }^{160} \mathrm{Nev}$ ertheless, microglial NF- $\kappa \mathrm{B}$ activation in brain ischemia appears to be largely neurotoxic.

AP-1 is another transcription factor known to promote microglial activation. AP-1 is a heterodimer comprised of c-Fos and c-Jun family proteins, which form dimers consisting of various subunits depending on the circumstances. These dimers bind to specific DNA regions, the AP-1 domains, which regulate the expression of a number of target genes (collectively referred to as late response genes). ${ }^{161}$ Like NF- $\kappa \mathrm{B}$, the activation of AP- 1 in microglia drives a proinflammatory response and the release of several cytotoxic agents. ${ }^{162-164}$

\section{PPAR $\gamma$}

The peroxisome proliferator activated receptor $\gamma$ $(\operatorname{PPAR} \gamma)$ is a ligand-activated transcription factor that forms heterodimers with retinoid $\mathrm{X}$ receptor in the cytosol, translocates to the nucleus, and binds to PPAR response domains in promoter regions of target genes. Target gene transcription may be either induced or suppressed by PPAR $\gamma$ binding, depending on whether it is bound to an activating ligand. ${ }^{165}$ The primary endogenous ligand for PPAR $\gamma$ is 15-deoxy-prostaglandin $\mathrm{J}_{2}$ (15d-PGJ2), and several synthetic ligands such as thiazolidinedione have now been generated. 
PPAR $\gamma$ expression in healthy brain is most prominent in glial cells, ${ }^{166}$ but occurs also in neurons. ${ }^{167,168}$ PPAR $\gamma$ expression in primary microglia cells is downregulated upon microglial activation, but introduction of the natural ligand, 15d-PGJ2, restores PPAR $\gamma$ expression and PPAR $\gamma$ DNA binding. ${ }^{169}$ Treatment with either natural or synthetic PPAR $\gamma$ ligands suppresses iNOS and MHC class II expression, inhibits COX-2 activity, and suppresses synthesis of PGE2, NO, TNF $\alpha$, IL- $1 \beta$, and IL-6 by cultured microglia. ${ }^{169-172}$ The anti-inflammatory effect of $15 \mathrm{~d}-\mathrm{PGJ} 2$ is mediated at least in part through suppression of STAT expression and a resultant increase in $\mathrm{I} \kappa \mathrm{B}$ expression, leading to decreased nuclear translocation of NF- $\kappa \mathrm{B}$ and thus decreased NF- $\kappa \mathrm{B}$ transcription activity. ${ }^{169,173}$ Moreover, at high concentrations $15 \mathrm{~d}-$ PGJ2 induces apoptosis in activated microglia. ${ }^{172}$

Cerebral ischemia increases PPAR $\gamma$ expression in neurons and microglia, but at the same time DNA binding of PPAR $\gamma$ is reduced. ${ }^{174}$ DNA binding is restored by PPAR $\gamma$ ligands, ${ }^{170,174,175}$ and these agents have been shown to reduce ischemic injury in rodent stroke models. ${ }^{176}$ Treatment with PPAR $\gamma$ ligands reduces microglia and macrophage activation and migration to the periinfarct regions, ${ }^{177,178}$ attenuates the expression of ICAM-1, MMP-9, IL-1 $\beta$, COX-2, TNF $\alpha$, and iNOS, and suppresses production of reactive oxygen species. ${ }^{177,179}$

\section{Nurr1 and progranulin}

Nurr1 is considered an orphan nuclear receptor. Nurr1 exerts anti-inflammatory effects by docking to NF- $\kappa \mathrm{B}-$ p65 on target inflammatory gene promoters in a signaldependent manner. Subsequently, Nurr1 recruits the CoREST corepressor complex, resulting in clearance of NF- $\kappa$ B p65 and transcriptional repression. ${ }^{180}$ Reduced Nurr1 expression results in exaggerated inflammatory responses in microglia. ${ }^{180}$

Progranulin is similarly expressed by macrophages and by microglia in brain. Macrophages from progranulin-deficient mice release less IL-10 and more inflammatory cytokines when exposed to bacterial lipopolysaccharide. Progranulin-deficient macrophages and microglia are cytotoxic to hippocampal cells in vitro, and progranulin-deficient hippocampal slices are hypersusceptible to deprivation of oxygen and glucose. ${ }^{181}$ The role of Nurr1 and progranulin in postischemic inflammation has not been reported.

\section{Glucocorticoids}

Glucocorticoids are endogenous immunosuppressants and are also widely used as pharmacological agents. Glucocorticoids bind to a cytoplasmic receptor that then alters gene expression in at least two ways. One way is by binding directly to DNA and acting as a transcription factor, promoting expression of proteins such as protein inhibitor of NF- $\kappa \mathrm{B}$. A second way is by binding to and interfering with actions of other transcription factors, such as NF- $\kappa \mathrm{B}$ and AP-1. ${ }^{182}$ Glucocorticoids can suppress ischemia-induced microglial activation in vivo ${ }^{183}$ and prevent microglia from inducing $\mathrm{T}$-cell proliferation and Th1 responses. ${ }^{184}$ However, this anti-inflammatory effect has not been shown to consistently reduce brain injury in experimental studies, and in some studies it worsened injury. ${ }^{185}$ These discrepancies may be due to other effects of glucocorticoids, such as potentiation of excitotoxicity and impaired glucose transport into neurons. ${ }^{186,187}$ There have been 22 clinical studies of glucocorticoid use in brain ischemia. A Cochrane review of seven of these trials that met prespecified criteria indicated that there was insufficient evidence to support their use. $^{188}$

\section{Other factors that influence proinflammatory gene transcription}

Several agents with neuroprotectant effects have been associated with NF- $\kappa \mathrm{B}$ blockade as a mechanism of action. These include HSP-70, pyruvate, sirtuins, PARP inhibitors, and minocycline.

Heat shock protein 70. A member of the stressinduced protein family, heat shock protein-70 (HSP-70) was originally identified as a chaperonin involved in the refolding of denatured proteins. ${ }^{189}$ Several studies have shown a protective role of HSP-70 in brain injury models, and it was subsequently shown that HSP-70 also suppresses ischemia-induced microglial activation and has anti-inflammatory effects in brain ischemia. ${ }^{190}$ This effect extends beyond ischemia, in that HSP-70 overexpression also inhibits bacterial lipopolysaccharide-induced cytokine production. ${ }^{191}$

HSP-70 is induced in a variety of CNS cells including microglia following experimental stroke. ${ }^{192}$ Using cocultures of astrocytes and microglia, HSP-70 transgenic microglia cultured with wild-type astrocytes experienced less injury to oxygen glucose deprivation (OGD) than did wild-type microglia cultured with wild-type astrocytes. ${ }^{193}$ In a transgenic mouse model of HSP-70 overexpression, protection from experimental stroke was associated with decreased microglial activation. ${ }^{193}$ Protein binding studies suggest that this is due to HSP-70 binding to the NF- $\kappa \mathrm{B}$ complex and blocking I $\kappa$ B phosphorylation. ${ }^{193}$

This anti-inflammatory may be due to the ability of HSP-70 to inhibit NF- $\kappa$ B activation. HSP-70 can interact with IKK, thereby preventing I $\kappa \mathrm{B}$ phosphorylation and activation. ${ }^{193,194}$ Glial cells exposed to heat shock or transfected with HSP-70 showed less nuclear NF $\kappa$ B translocation and less iNOS expression (NF $\kappa \mathrm{B}$-regulated protein) when treated with bacterial lipopolysaccharide. ${ }^{195}$ Similarly, in brain inflammation elicited by bacterial lipopolysaccharide and cytokine injection, prior heat stress led to less microglial activation and less NF $\kappa$ B activity. ${ }^{196}$ 
Pyruvate. A final metabolite in glycolysis, pyruvate has recently been shown to have salutary effects in brain ischemia. ${ }^{197-200}$ The mechanism of this protective effect is unclear, but it has been correlated with reduction in microglial activation and suppression of proinflammatory cytokines following focal cerebral ischemia. At the in vitro level, ethyl pyruvate (a prodrug form of pyruvate with improved brain penetrance) was found to inhibit NF- $\kappa \mathrm{B}$ activation in both cultured microglia and RAW 264.7 cells through a modification of the p65 subunit. ${ }^{201-203}$ Ethyl pyruvate also reduced mortality and reduced circulating levels of HMGB1 in a model of lethal sepsis. ${ }^{202}$ Further, pyruvate was also shown to inhibit microglial NF- $\kappa \mathrm{B}$ activation in rats given bacterial lipopolysaccharide, which causes transient microglial activation independent of any cell death. ${ }^{200}$ Thus, pyruvate may directly inhibit microglial activation.

Sirtuins. The sirtuins belong to the class III histone deacetylase family and include seven members, SIRT1-7. Sirtuins require $\mathrm{NAD}^{+}$as a cofactor to deacetylate lysine residues on histones and other substrates, including NF- $\kappa$ B. SIRT1 deacetylation of the p65 NF- $\kappa$ B subunit inhibits NF- $\kappa$ B transcription complex formation. ${ }^{204}$ Microglia overexpressing SIRT1 have reduced NF- $\kappa \mathrm{B}$ activity and exhibit reduced neurotoxicity upon amyloid- $\beta$ stimulation. ${ }^{205}$ Conversely, SIRT1 inhibition or depletion in macrophage cultures has been shown to increase MMP-9 expression and TNF $\alpha$ secretion via promotion of NF- $\kappa \mathrm{B}$ transcriptional activity. ${ }^{206,207}$

Cerebral ischemia results in altered SIRT1 protein and activity levels in brain. ${ }^{208}$ Sirtuin activity is reduced within the first 6 hours after ischemic injury, but is then is increased at 12 and 24 hours. Resveratrol, a potent SIRT1 activator, has neuroprotective effects in cerebral ischemia, ${ }^{209-211}$ but whether this effect is mediated through actions on microglia remains to be established.

PARP inhibitors. Poly(ADP-ribose) polymerase-1 (PARP-1) is an abundant nuclear enzyme involved in both DNA repair and transcriptional regulation. ${ }^{212}$ PARP-1 activation can be detected in activated microglia, and PARP-1 depletion or inhibition prevents microglial morphological transformation, proliferation, migration to injury site, release of cytokines, reactive oxygen species, and MMP-9. ${ }^{22,213,214}$ PARP-1 interacts with NF- $\kappa$ B, AP-1, and other proinflammatory transcription factors. ${ }^{215-217}$ PARP-1 enzymatic activity is required for NF- $\kappa \mathrm{B}-\mathrm{me}-$ diated gene transcription and for many of the inflammatory responses in microglia. ${ }^{22,214,218,219}$

Several PARP inhibitors are now commercially available. Most of these do not discriminate well between PARP-1 and several of the other PARP species, but studies using PARP- $1^{-/-}$cells indicate a major, though perhaps not exclusive role for the PARP-1 isoform in microglial activation. ${ }^{213,214,220}$ In microglia-neuron co- cultures, both PARP inhibition and PARP-1 genetic deficiency prevent the neurotoxicity resulting from $\mathrm{TNF} \alpha$ induced microglial MMP-9 release. ${ }^{214}$ PARP-1 also induces nuclear to cytosol translocation of HMGB1 from dying cells. ${ }^{89}$ Neuronal HMGB1 release has shown to promote inflammation and increase ischemic injury. ${ }^{88}$

Immunohistochemical studies of brain infarcts in human brain show PARP activation in microglia up to 3 weeks after an ischemic insult. ${ }^{221}$ Several studies using animal models have shown a reduction in poststroke microglial activation by acute administration of PARP inhibitors, ${ }^{222,223}$ but this anti-inflammatory effect is difficult to interpret, given that acute administration of PARP inhibitors also has a neuroprotective effect ${ }^{224-226}$ that could independently reduce the subsequent inflammatory response. Nonetheless, PARP-1 inhibition begun 2 days after ischemia to selectively target the inflammatory response also reduced microglial activation and improved long-term outcomes, ${ }^{227}$ suggesting a direct effect on poststroke inflammation in vivo.

Of note, minocycline is an extremely potent PARP-1 inhibitor, ${ }^{51}$ and the anti-inflammatory effects of minocycline may be attributable to this effect on PARP-1. Minocycline was shown to suppress microglial activation and improve neuronal survival after brain ischemia. ${ }^{28,229}$ Minocycline and other PARP-1 inhibitors are entering clinical trials for treatment of stroke and other conditions. ${ }^{230-232}$

\section{CONCLUSIONS}

Brain inflammation develops over a time period of hours to days after ischemia onset, a time window conducive to therapeutic intervention. Effective agents are now available for blocking both the microglial receptor activation and microglia effector responses that drive the inflammatory response after stroke. Agents are also available for targeting the signal transduction mechanisms linking these events. Studies have already shown some of these agents to have beneficial effects on stroke outcome in animal models. In most of these studies, however, treatment was initiated at very short time points after ischemia, and this prevents any mechanistic distinction between agents that directly suppress microglial activation and those that suppress microglial activation only as a result of reduced cell injury. A more focused evaluation of the efficacy of these agents as anti-inflammatory drugs will require a delayed onset of treatment, in order to permit this mechanistic distinction and to more closely model treatment in the clinical stroke setting. An additional consideration is that the majority of the animal studies cited in this review used stroke models involving reperfusion after relatively short periods of ischemia. This stands in contrast to clinical stroke, in which reperfusion is more commonly delayed by many hours or 
days, and therefore conclusions based on animal models with short periods of ischemia may not accurately guide human therapeutics. Last, it will be important to remain cognizant of the potential beneficial effects of inflammation on stroke outcome. A primary challenge in this field will be finding ways to suppress microglial activation without negatively impacting these beneficial effects.

Acknowledgments: This work was supported by the Department of Veterans Affairs (R.A.S., M.A.Y.), the Department of Defense (W81XH-05-2-0094, R.A.S.; DAMD17-03-1-0532, M.A.Y.), the National Institutes of Health (NS14543, R.A.S.; NS40516, M.A.Y.), and the American Heart Association (0835222N, T.M.K.).

\section{REFERENCES}

1. Wang Q, Tang XN, Yenari MA. The inflammatory response in stroke J Neuroimmunol 2007;184:53-68.

2. Chamorro A, Hallenbeck J. The harms and benefits of inflammatory and immune responses in vascular disease. Stroke 2006;37: 291-293.

3. Monje ML, Toda H, Palmer TD. Inflammatory blockade restores adult hippocampal neurogenesis. Science 2003;302:1760-1765.

4. Ekdahl CT, Claasen JH, Bonde S, Kokaia Z, Lindvall O. Inflammation is detrimental for neurogenesis in adult brain. Proc Natl Acad Sci U S A 2003;100:13632-13637.

5. Kriz J. Inflammation in ischemic brain injury: timing is important. Crit Rev Neurobiol 2006;18:145-157.

6. Ginsberg MD. Neuroprotection for ischemic stroke: past, present and future. Neuropharmacology 2008;55:363-389.

7. Kreutzberg GW. Microglia: a sensor for pathological events in the CNS. Trends Neurosci 1996;19:312-318.

8. El Khoury J, Hickman SE, Thomas CA, Loike JD, Silverstein SC. Microglia, scavenger receptors, and the pathogenesis of Alzheimer's disease. Neurobiol Aging 1998;19(1 Suppl):S81-S84.

9. Thomas WE. Brain macrophages: evaluation of microglia and their functions. Brain Res Brain Res Rev 1992;17:61-74.

10. Zheng Z, Yenari MA. Post-ischemic inflammation: molecular mechanisms and therapeutic implications. Neurol Res 2004;26: 884-892.

11. Ransohoff RM, Perry VH. Microglial physiology: unique stimuli, specialized responses. Annu Rev Immunol 2009;27:119-145.

12. Carson MJ, Bilousova TV, Puntambekar SS, Melchior B, Doose JM, Ethell IM. A rose by any other name? The potential consequences of microglial heterogeneity during CNS health and disease. Neurotherapeutics 2007;4:571-579.

13. Yenari MA, Xu L, Tang XN, Qiao Y, Giffard RG. Microglia potentiate damage to blood-brain barrier constituents: improvement by minocycline in vivo and in vitro. Stroke 2006;37:10871093.

14. Lehnardt S, Massillon L, Follett $\mathrm{P}$, et al. Activation of innate immunity in the CNS triggers neurodegeneration through a Tolllike receptor 4-dependent pathway. Proc Natl Acad Sci U S A 2003;100:8514-8519.

15. Giulian D, Corpuz M, Chapman S, Mansouri M, Robertson C. Reactive mononuclear phagocytes release neurotoxins after ischemic and traumatic injury to the central nervous system. J Neurosci Res 1993;36:681-693.

16. Jordán J, Segura T, Brea D, Galindo MF, Castillo J. Inflammation as therapeutic objective in stroke. Curr Pharm Des 2008;14: 3549-3564.

17. Hamby AM, Suh SW, Kauppinen TM, Swanson RA. Use of a poly(ADP-ribose) polymerase inhibitor to suppress inflammation and neuronal death after cerebral ischemia-reperfusion. Stroke 2007;38(2 Suppl):632-636.

18. Chou WH, Choi DS, Zhang H, et al. Neutrophil protein kinase $\mathrm{C} \delta$ as a mediator of stroke-reperfusion injury. J Clin Invest 2004; 114:49-56.
19. Watanabe H, Abe H, Takeuchi S, Tanaka R. Protective effect of microglial conditioning medium on neuronal damage induced by glutamate. Neurosci Lett 2000;289:53-56.

20. Zhao BQ, Wang S, Kim HY, et al. Role of matrix metalloproteinases in delayed cortical responses after stroke. Nat Med 2006; 12:441-445.

21. Mander PK, Jekabsone A, Brown GC. Microglia proliferation is regulated by hydrogen peroxide from NADPH oxidase. J Immunol 2006;176:1046-1052.

22. Kauppinen TM, Higashi Y, Suh SW, Escartin C, Nagasawa K, Swanson RA. Zinc triggers microglial activation. J Neurosci 2008;28:5827-5835.

23. Groemping Y, Rittinger K. Activation and assembly of the NADPH oxidase: a structural perspective. Biochem J 2005;386: 401-416.

24. Lambeth JD. NOX enzymes and the biology of reactive oxygen. Nat Rev Immunol 2004;4:181-189.

25. Suh SW, Shin BS, Ma H, et al. Glucose and NADPH oxidase drive neuronal superoxide formation in stroke. Ann Neurol 2008; 64:654-663.

26. Decoursey TE, Ligeti E. Regulation and termination of NADPH oxidase activity. Cell Mol Life Sci 2005;62:2173-2193.

27. Kahles T, Luedike P, Endres M, et al. NADPH oxidase plays a central role in blood-brain barrier damage in experimental stroke. Stroke 2007;38:3000-3006.

28. Walder CE, Green SP, Darbonne WC, et al. Ischemic stroke injury is reduced in mice lacking a functional NADPH oxidase. Stroke 1997;28:2252-2258.

29. Chen H, Song YS, Chan PH. Inhibition of NADPH oxidase is neuroprotective after ischemia-reperfusion. J Cereb Blood Flow Metab 2009;29:1262-1272.

30. Tang J, Liu J, Zhou C, et al. Role of NADPH oxidase in the brain injury of intracerebral hemorrhage. J Neurochem 2005;94:13421350.

31. Tang LL, Ye K, Yang XF, Zheng JS. Apocynin attenuates cerebral infarction after transient focal ischaemia in rats. J Int Med Res 2007;35:517-522.

32. Tang XN, Cairns B, Cairns N, Yenari MA. Apocynin improves outcome in experimental stroke with a narrow dose range. Neuroscience 2008;154:556-562.

33. Wang Q, Tompkins KD, Simonyi A, Korthuis RJ, Sun AY, Sun GY. Apocynin protects against global cerebral ischemia-reperfusion-induced oxidative stress and injury in the gerbil hippocampus. Brain Res 2006;1090:182-189.

34. Liou KT, Shen YC, Chen CF, Tsao CM, Tsai SK. Honokiol protects rat brain from focal cerebral ischemia-reperfusion injury by inhibiting neutrophil infiltration and reactive oxygen species production. Brain Res 2003;992:159-166.

35. Chen CM, Liu SH, Lin-Shiau SY. Honokiol, a neuroprotectant against mouse cerebral ischaemia, mediated by preserving $\mathrm{Na}^{+}$, $\mathrm{K}^{+}$-ATPase activity and mitochondrial functions. Basic Clin Pharmacol Toxicol 2007;101:108-116.

36. Iadecola C, Zhang F, Xu S, Casey R, Ross ME. Inducible nitric oxide synthase gene expression in brain following cerebral ischemia. J Cereb Blood Flow Metab 1995;15:378-384.

37. Iadecola C, Zhang F, Xu X. Inhibition of inducible nitric oxide synthase ameliorates cerebral ischemic damage. Am J Physiol 1995;268:R286-R292.

38. Beckman JS, Koppenol WH. Nitric oxide, superoxide, and peroxynitrite: the good, the bad, and ugly. Am J Physiol 1996;271: C1424-C1437.

39. Zhao X, Haensel C, Araki E, Ross ME, Iadecola C. Gene-dosing effect and persistence of reduction in ischemic brain injury in mice lacking inducible nitric oxide synthase. Brain Res 2000;872: 215-218.

40. Han HS, Qiao Y, Karabiyikoglu M, Giffard RG, Yenari MA Influence of mild hypothermia on inducible nitric oxide synthase expression and reactive nitrogen production in experimental stroke and inflammation. J Neurosci 2002;22:3921-3928.

41. Rosenberg GA. Matrix metalloproteinases in neuroinflammation [Erratum in: Glia 2002;40:130]. Glia 2002;39:279-291.

42. Candelario-Jalil E, Yang Y, Rosenberg GA. Diverse roles of matrix metalloproteinases and tissue inhibitors of metalloprotein- 
ases in neuroinflammation and cerebral ischemia. Neuroscience 2009;158:983-994.

43. Rosenberg GA, Cunningham LA, Wallace J, et al. Immunohistochemistry of matrix metalloproteinases in reperfusion injury to rat brain: activation of MMP-9 linked to stromelysin-1 and microglia in cell cultures. Brain Res 2001;893:104-112.

44. del Zoppo GJ, Milner R, Mabuchi T, et al. Microglial activation and matrix protease generation during focal cerebral ischemia. Stroke 2007;38:646-651.

45. Pfefferkorn T, Rosenberg GA. Closure of the blood-brain barrier by matrix metalloproteinase inhibition reduces rtPA-mediated mortality in cerebral ischemia with delayed reperfusion. Stroke 2003;34:2025-2030.

46. Asahi M, Asahi K, Jung JC, del Zoppo GJ, Fini ME, Lo EH. Role for matrix metalloproteinase 9 after focal cerebral ischemia: effects of gene knockout and enzyme inhibition with BB-94. J Cereb Blood Flow Metab 2000;20:1681-1689.

47. Walker EJ, Rosenberg GA. TIMP-3 and MMP-3 contribute to delayed inflammation and hippocampal neuronal death following global ischemia. Exp Neurol 2009;216:122-131.

48. Koistinaho M, Malm TM, Kettunen MI, et al. Minocycline protects against permanent cerebral ischemia in wild type but not in matrix metalloprotease-9-deficient mice. J Cereb Blood Flow Metab 2005;25:460-467.

49. Lee H, Park JW, Kim SP, Lo EH, Lee SR. Doxycycline inhibits matrix metalloproteinase-9 and laminin degradation after transient global cerebral ischemia. Neurobiol Dis 2009;34:189-198.

50. Machado LS, Kozak A, Ergul A, Hess DC, Borlongan CV, Fagan SC. Delayed minocycline inhibits ischemia-activated matrix metalloproteinases 2 and 9 after experimental stroke. BMC Neurosci 2006; 7:56

51. Alano CC, Kauppinen TM, Valls AV, Swanson RA. Minocycline inhibits poly(ADP-ribose) polymerase-1 at nanomolar concentrations. Proc Natl Acad Sci U S A 2006;103:9685-9690.

52. Takeuchi H, Jin S, Wang J, et al. Tumor necrosis factor- $\alpha$ induces neurotoxicity via glutamate release from hemichannels of activated microglia in an autocrine manner. J Biol Chem 2006;281: 21362-21368.

53. Takeuchi H, Jin S, Suzuki H, et al. Blockade of microglial glutamate release protects against ischemic brain injury. Exp Neurol 2008;214:144-146.

54. Zhao W, Xie W, Le W, et al. Activated microglia initiate motor neuron injury by a nitric oxide and glutamate-mediated mechanism. J Neuropathol Exp Neurol 2004;63:964-977.

55. Shaked I, Tchoresh D, Gersner R, et al. Protective autoimmunity: interferon- $\gamma$ enables microglia to remove glutamate without evoking inflammatory mediators. J Neurochem 2005;92: 997-1009.

56. Lucas SM, Rothwell NJ, Gibson RM. The role of inflammation in CNS injury and disease. Br J Pharmacol 2006;147 Suppl 1:S232S240.

57. Shohami E, Ginis I, Hallenbeck JM. Dual role of tumor necrosis factor $\alpha$ in brain injury. Cytokine Growth Factor Rev 1999;10: 119-130.

58. Vexler ZS, Tang XN, Yenari MA. Inflammation in adult and neonatal stroke. Clin Neurosci Res 2006;6:293-313.

59. Lehrmann E, Kiefer R, Christensen T, et al. Microglia and macrophages are major sources of locally produced transforming growth factor- $\beta 1$ after transient middle cerebral artery occlusion in rats. Glia 1998;24:437-448.

60. Suzuki S, Tanaka K, Nogawa S, et al. Temporal profile and cellular localization of interleukin-6 protein after focal cerebral ischemia in rats. J Cereb Blood Flow Metab 1999;19:1256-1262.

61. Lee TH, Kato H, Chen ST, Kogure K, Itoyama Y. Expression disparity of brain-derived neurotrophic factor immunoreactivity and mRNA in ischemic hippocampal neurons. Neuroreport 2002; 13:2271-2275.

62. Sperlágh B, Illes P. Purinergic modulation of microglial cell activation. Purinergic Signal 2007;3:117-127.

63. Franke H, Günther A, Grosche J, et al. P2X7 receptor expression after ischemia in the cerebral cortex of rats. J Neuropathol Exp Neurol 2004;63:686-699.
64. Monif M, Reid CA, Powell KL, Smart ML, Williams DA. The P2X7 receptor drives microglial activation and proliferation: a trophic role for P2X7R pore. J Neurosci 2009;29:3781-3791.

65. Bianco F, Ceruti S, Colombo A, et al. A role for P2X7 in microglial proliferation. J Neurochem 2006;99:745-758.

66. Parvathenani LK, Tertyshnikova S, Greco CR, Roberts SB, Robertson B, Posmantur R. P2X7 mediates superoxide production in primary microglia and is up-regulated in a transgenic mouse model of Alzheimer's disease. J Biol Chem 2003;278:13309_ 13317.

67. Takenouchi T, Sugama S, Iwamaru Y, Hashimoto M, Kitani H. Modulation of the ATP-lnduced release and processing of IL-1 $\beta$ in microglial cells. Crit Rev Immunol 2009;29:335-345.

68. Brough D, Le Feuvre RA, Iwakura Y, Rothwell NJ. Purinergic (P2X7) receptor activation of microglia induces cell death via an interleukin-1-independent mechanism. Mol Cell Neurosci 2002; 19:272-280.

69. Suzuki T, Hide I, Ido K, Kohsaka S, Inoue K, Nakata Y. Production and release of neuroprotective tumor necrosis factor by P2X7 receptor-activated microglia. J Neurosci 2004;24:1-7.

70. Fang KM, Yang CS, Sun SH, Tzeng SF. Microglial phagocytosis attenuated by short-term exposure to exogenous ATP through P2X receptor action. J Neurochem 2009;111:1225-1237.

71. Haynes SE, Hollopeter G, Yang G, et al. The P2Y12 receptor regulates microglial activation by extracellular nucleotides. Nat Neurosci 2006;9:1512-1519.

72. Ohsawa K, Irino $\mathrm{Y}$, Sanagi $\mathrm{T}$, et al. $\mathrm{P} 2 \mathrm{Y}_{12}$ receptor-mediated integrin- $\beta 1$ activation regulates microglial process extension induced by ATP. Glia 2010;58:790-801.

73. Ralevic V, Burnstock G. Receptors for purines and pyrimidines. Pharmacol Rev 1998;50:413-492.

74. Anderson CM, Bergher JP, Swanson RA. ATP-induced ATP release from astrocytes. J Neurochem 2004;88:246-256.

75. Peng W, Cotrina ML, Han X, et al. Systemic administration of an antagonist of the ATP-sensitive receptor P2X7 improves recovery after spinal cord injury. Proc Natl Acad Sci U S A 2009;106: 12489-12493.

76. Melani A, Amadio S, Gianfriddo M, et al. P2X7 receptor modulation on microglial cells and reduction of brain infarct caused by middle cerebral artery occlusion in rat. J Cereb Blood Flow Metab 2006;26:974-982.

77. Yanagisawa D, Kitamura Y, Takata K, Hide I, Nakata Y, Taniguchi T. Possible involvement of $\mathrm{P} 2 \mathrm{X} 7$ receptor activation in microglial neuroprotection against focal cerebral ischemia in rats. Biol Pharm Bull 2008;31:1121-1130.

78. Kilic U, Kilic E, Matter CM, Bassetti CL, Hermann DM. TLR-4 deficiency protects against focal cerebral ischemia and axotomyinduced neurodegeneration. Neurobiol Dis 2008;31:33-40.

79. Tang SC, Arumugam TV, Xu X, et al. Pivotal role for neuronal Toll-like receptors in ischemic brain injury and functional deficits. Proc Natl Acad Sci U S A 2007;104:13798-13803.

80. Hua F, Ma J, Ha T, et al. Activation of Toll-like receptor 4 signaling contributes to hippocampal neuronal death following global cerebral ischemia/reperfusion. J Neuroimmunol 2007;190: 101-111.

81. Caso JR, Pradillo JM, Hurtado O, Lorenzo P, Moro MA, Lizasoain I. Toll-like receptor 4 is involved in brain damage and inflammation after experimental stroke. Circulation 2007;115: 1599-1608.

82. Lehnardt S, Schott E, Trimbuch T, et al. A vicious cycle involving release of heat shock protein 60 from injured cells and activation of Toll-like receptor 4 mediates neurodegeneration in the CNS. J Neurosci 2008;28:2320-2331.

83. Pradillo JM, Fernandez-Lopez D, Garcia-Yebenes I, et al. Tolllike receptor 4 is involved in neuroprotection afforded by ischemic preconditioning. J Neurochem 2009;109:287-294.

84. Marsh B, Stevens SL, Packard AE, et al. Systemic lipopolysaccharide protects the brain from ischemic injury by reprogramming the response of the brain to stroke: a critical role for IRF3. J Neurosci 2009;29:9839-9849.

85. Marsh BJ, Williams-Karnesky RL, Stenzel-Poore MP. Toll-like receptor signaling in endogenous neuroprotection and stroke. Neuroscience 2009;158:1007-1020. 
86. Stevens SL, Ciesielski TM, Marsh BJ, et al. Toll-like receptor 9: a new target of ischemic preconditioning in the brain. $\mathrm{J}$ Cereb Blood Flow Metab 2008;28:1040-1047.

87. Ulloa L, Batliwalla FM, Andersson U, Gregersen PK, Tracey KJ. High mobility group box chromosomal protein 1 as a nuclear protein, cytokine, and potential therapeutic target in arthritis. Arthritis Rheum 2003;48:876-881.

88. Faraco G, Fossati S, Bianchi ME, et al. High mobility group box 1 protein is released by neural cells upon different stresses and worsens ischemic neurodegeneration in vitro and in vivo. J Neurochem 2007;103:590-603.

89. Ditsworth D, Zong WX, Thompson CB. Activation of poly(ADP)-ribose polymerase (PARP-1) induces release of the proinflammatory mediator HMGB1 from the nucleus [Erratum in: J Biol Chem 2009;284:22500]. J Biol Chem 2007;282:1784517854 .

90. Qiu J, Nishimura M, Wang Y, et al. Early release of HMGB-1 from neurons after the onset of brain ischemia. J Cereb Blood Flow Metab 2008;28:927-938.

91. Tarozzo G, Campanella M, Ghiani M, Bulfone A, Beltramo M. Expression of fractalkine and its receptor, $\mathrm{CX} 3 \mathrm{CR} 1$, in response to ischaemia-reperfusion brain injury in the rat. Eur $\mathrm{J}$ Neurosci 2002;15:1663-1668.

92. Cotter R, Williams C, Ryan L, et al. Fractalkine (CX3CL1) and brain inflammation: implications for HIV-1-associated dementia. J Neurovirol 2002;8:585-598.

93. Soriano SG, Coxon A, Wang YF, et al. Mice deficient in Mac-1 (CD11b/CD18) are less susceptible to cerebral ischemia/reperfusion injury. Stroke 1999;30:134-139.

94. Dénes A, Ferenczi S, Halász J, Környei Z, Kovács KJ. Role of CX3CR1 (fractalkine receptor) in brain damage and inflammation induced by focal cerebral ischemia in mouse. J Cereb Blood Flow Metab 2008;28:1707-1721.

95. Dorgham K, Ghadiri A, Hermand P, et al. An engineered CX3CR1 antagonist endowed with anti-inflammatory activity. J Leukoc Biol 2009;86:903-911.

96. Streit WJ, Davis CN, Harrison JK. Role of fractalkine (CX3CL1) in regulating neuron-microglia interactions: development of viralbased CX3CR1 antagonists. Curr Alzheimer Res 2005;2:187189.

97. Cimino PJ, Keene CD, Breyer RM, Montine KS, Montine TJ. Therapeutic targets in prostaglandin E2 signaling for neurologic disease. Curr Med Chem 2008;15:1863-1869.

98. Andreasson K. Emerging roles of PGE2 receptors in models of neurological disease. Prostaglandins Other Lipid Mediat 2009;91: 104-112.

99. Shie FS, Montine KS, Breyer RM, Montine TJ. Microglial EP2 is critical to neurotoxicity from activated cerebral innate immunity. Glia 2005;52:70-77.

100. Noda M, Nakanishi H, Nabekura J, Akaike N. AMPA-kainate subtypes of glutamate receptor in rat cerebral microglia. J Neurosci 2000;20:251-258.

101. Tikka TM, Koistinaho JE. Minocycline provides neuroprotection against $N$-methyl-D-aspartate neurotoxicity by inhibiting microglia. J Immunol 2001;166:7527-7533.

102. Kaur C, Sivakumar V, Ling EA. Expression of $N$-methyl-Daspartate (NMDA) and $\alpha$-amino-3-hydroxy-5-methyl-4-isoxazolepropionate (AMPA) GluR2/3 receptors in the developing rat pineal gland. J Pineal Res 2005;39:294-301.

103. Christensen RN, Ha BK, Sun F, Bresnahan JC, Beattie MS. Kainate induces rapid redistribution of the actin cytoskeleton in ameboid microglia. J Neurosci Res 2006;84:170-181.

104. Liu GJ, Kalous A, Werry EL, Bennett MR. Purine release from spinal cord microglia after elevation of calcium by glutamate. Mol Pharmacol 2006;70:851-859.

105. Biber K, Laurie DJ, Berthele A, et al. Expression and signaling of group I metabotropic glutamate receptors in astrocytes and microglia. J Neurochem 1999;72:1671-1680.

106. Taylor DL, Diemel LT, Cuzner ML, Pocock JM. Activation of group II metabotropic glutamate receptors underlies microglial reactivity and neurotoxicity following stimulation with chromogranin A, a peptide up-regulated in Alzheimer's disease. J Neurochem 2002;82:1179-1191.
107. Pinteaux-Jones F, Sevastou IG, Fry VA, Heales S, Baker D, Pocock JM. Myelin-induced microglial neurotoxicity can be controlled by microglial metabotropic glutamate receptors. J Neurochem 2008; 106:442-454.

108. Ferraguti F, Shigemoto R. Metabotropic glutamate receptors. Cell Tissue Res 2006;326:483-504.

109. Tikka T, Fiebich BL, Goldsteins G, Keinanen R, Koistinaho J. Minocycline, a tetracycline derivative, is neuroprotective against excitotoxicity by inhibiting activation and proliferation of microglia. J Neurosci 2001;21:2580-2588.

110. Taylor DL, Diemel LT, Pocock JM. Activation of microglial group III metabotropic glutamate receptors protects neurons against microglial neurotoxicity. J Neurosci 2003;23:2150-2160.

111. Byrnes KR, Stoica B, Loane DJ, Riccio A, Davis MI, Faden AI. Metabotropic glutamate receptor 5 activation inhibits microglial associated inflammation and neurotoxicity. Glia 2009;57:550560.

112. Liang J, Takeuchi H, Jin S, et al. Glutamate induces neurotrophic factor production from microglia via protein kinase $\mathrm{C}$ pathway. Brain Res 2010;1322:8-23.

113. Geurts JJ, Wolswijk G, Bö L, et al. Altered expression patterns of group I and II metabotropic glutamate receptors in multiple sclerosis. Brain 2003;126:1755-1766.

114. Gottlieb M, Matute C. Expression of ionotropic glutamate receptor subunits in glial cells of the hippocampal CA1 area following transient forebrain ischemia. J Cereb Blood Flow Metab 1997; 17:290-300.

115. Kohara A, Takahashi M, Yatsugi S, et al. Neuroprotective effects of the selective type 1 metabotropic glutamate receptor antagonist YM-202074 in rat stroke models. Brain Res 2008;1191:168-179.

116. Byrnes KR, Stoica B, Riccio A, Pajoohesh-Ganji A, Loane DJ, Faden AI. Activation of metabotropic glutamate receptor 5 improves recovery after spinal cord injury in rodents. Ann Neurol 2009;66:63-74.

117. N'Diaye EN, Branda CS, Branda SS, et al. TREM-2 (triggering receptor expressed on myeloid cells 2) is a phagocytic receptor for bacteria. J Cell Biol 2009;184:215-223.

118. Sessa G, Podini P, Mariani M, et al. Distribution and signaling of TREM2/DAP12, the receptor system mutated in human polycystic lipomembraneous osteodysplasia with sclerosing leukoencephalopathy dementia. Eur J Neurosci 2004;20:2617-2628.

119. Takahashi K, Rochford CD, Neumann H. Clearance of apoptotic neurons without inflammation by microglial triggering receptor expressed on myeloid cells-2. J Exp Med 2005;201:647-657.

120. Daws MR, Lanier LL, Seaman WE, Ryan JC. Cloning and characterization of a novel mouse myeloid DAP12-associated receptor family. Eur J Immunol 2001;31:783-791.

121. Hsieh CL, Koike M, Spusta SC, et al. A role for TREM2 ligands in the phagocytosis of apoptotic neuronal cells by microglia. J Neurochem 2009;109:1144-1156.

122. Stefano L, Racchetti G, Bianco F, et al. The surface-exposed chaperone, Hsp60, is an agonist of the microglial TREM2 receptor. J Neurochem 2009;110:284-294.

123. Daws MR, Sullam PM, Niemi EC, Chen TT, Tchao NK, Seaman WE. Pattern recognition by TREM-2: binding of anionic ligands. J Immunol 2003;171:594-599.

124. Soltys BJ, Gupta RS. Mitochondrial proteins at unexpected cellular locations: export of proteins from mitochondria from an evolutionary perspective. Int Rev Cytol 2000;194:133-196.

125. Lanier LL, Corliss BC, Wu J, Leong C, Phillips JH. Immunoreceptor DAP12 bearing a tyrosine-based activation motif is involved in activating NK cells. Nature 1998;391:703-707.

126. McVicar DW, Taylor LS, Gosselin P, et al. DAP12-mediated signal transduction in natural killer cells: a dominant role for the Syk protein-tyrosine kinase. J Biol Chem 1998;273:32934-32942.

127. Colonna M. TREMs in the immune system and beyond. Nat Rev Immunol 2003;3:445-453.

128. Bouchon A, Hernández-Munain C, Cella M, Colonna M. A DAP12-mediated pathway regulates expression of CC chemokine receptor 7 and maturation of human dendritic cells. J Exp Med 2001;194:1111-1122.

129. Piccio L, Buonsanti C, Mariani M, et al. Blockade of TREM-2 
exacerbates experimental autoimmune encephalomyelitis. Eur J Immunol 2007;37:1290-1301.

130. Frederickson CJ, Koh JY, Bush AI. The neurobiology of zinc in health and disease. Nat Rev Neurosci 2005;6:449-462.

131. Beaulieu C, Dyck R, Cynader M. Enrichment of glutamate in zinc-containing terminals of the cat visual cortex. Neuroreport 1992;3:861-864.

132. Frederickson CJ. Neurobiology of zinc and zinc-containing neurons. Int Rev Neurobiol 1989;31:145-238.

133. Danscher G, Howell G, Perez-Clausell J, Hertel N. The dithizone, Timm's sulphide silver and the selenium methods demonstrate a chelatable pool of zinc in CNS: a proton activation (PIXE) analysis of carbon tetrachloride extracts from rat brains and spinal cords intravitally treated with dithizone. Histochemistry $1985 ; 83$ : $419-422$.

134. Howell GA, Welch MG, Frederickson CJ. Stimulation-induced uptake and release of zinc in hippocampal slices. Nature 1984; 308:736-738.

135. Assaf SY, Chung SH. Release of endogenous $\mathrm{Zn} 2^{+}$from brain tissue during activity. Nature 1984;308:734-736.

136. Lee JY, Kim JH, Palmiter RD, Koh JY. Zinc released from metallothionein-iii may contribute to hippocampal CA1 and thalamic neuronal death following acute brain injury. Exp Neurol 2003;184:337-347.

137. Koh JY, Suh SW, Gwag BJ, He YY, Hsu CY, Choi DW. The role of zinc in selective neuronal death after transient global cerebral ischemia. Science 1996;272:1013-1016.

138. Calderone A, Jover T, Mashiko T, et al. Late calcium EDTA rescues hippocampal CA1 neurons from global ischemia-induced death. J Neurosci 2004;24:9903-9913.

139. Suh SW, Garnier P, Aoyama K, Chen Y, Swanson RA. Zinc release contributes to hypoglycemia-induced neuronal death. Neurobiol Dis 2004;16:538-545.

140. Suh SW, Chen JW, Motamedi M, et al. Evidence that synaptically-released zinc contributes to neuronal injury after traumatic brain injury. Brain Res 2000;852:268-273.

141. Cherny RA, Atwood CS, Xilinas ME, et al. Treatment with a copper-zinc chelator markedly and rapidly inhibits $\beta$-amyloid accumulation in Alzheimer's disease transgenic mice. Neuron 2001;30:665-676.

142. Nguyen T, Hamby A, Massa SM. Clioquinol down-regulates mutant huntingtin expression in vitro and mitigates pathology in a Huntington's disease mouse model. Proc Natl Acad Sci U S A 2005;102:11840-11845.

143. Barone FC, Feuerstein GZ. Inflammatory mediators and stroke: new opportunities for novel therapeutics. J Cereb Blood Flow Metab 1999;19:819-834.

144. Irving EA, Bamford M. Role of mitogen- and stress-activated kinases in ischemic injury. J Cereb Blood Flow Metab 2002;22: 631-647.

145. Irving EA, Barone FC, Reith AD, Hadingham SJ, Parsons AA. Differential activation of MAPK/ERK and p38/SAPK in neurones and glia following focal cerebral ischaemia in the rat. Brain Res Mol Brain Res 2000;77:65-75.

146. Sugino T, Nozaki K, Takagi Y, et al. Activation of mitogenactivated protein kinases after transient forebrain ischemia in gerbil hippocampus. J Neurosci 2000;20:4506-4514.

147. Kyriakis JM, Avruch J. Mammalian mitogen-activated protein kinase signal transduction pathways activated by stress and inflammation. Physiol Rev 2001;81:807-869.

148. Tian D, Litvak V, Lev S. Cerebral ischemia and seizures induce tyrosine phosphorylation of PYK2 in neurons and microglial cells. J Neurosci 2000;20:6478-6487.

149. Walton KM, DiRocco R, Bartlett BA, et al. Activation of $\mathrm{p} 38^{\mathrm{MAPK}}$ in microglia after ischemia. J Neurochem 1998;70:1764-1767.

150. Koistinaho M, Kettunen MI, Goldsteins G, et al. $\beta$-Amyloid precursor protein transgenic mice that harbor diffuse $\mathrm{A} \beta$ deposits but do not form plaques show increased ischemic vulnerability: role of inflammation. Proc Natl Acad Sci U S A 2002;99:16101615.

151. Kauppinen TM, Chan WY, Suh SW, Wiggins AK, Huang EJ, Swanson RA. Direct phosphorylation and regulation of poly-
(ADP-ribose) polymerase-1 by extracellular signal-regulated kinases 1/2. Proc Natl Acad Sci U S A 2006;103:7136-7141.

152. Legos JJ, Erhardt JA, White RF, et al. SB 239063, a novel p38 inhibitor, attenuates early neuronal injury following ischemia. Brain Res 2001;892:70-77.

153. Barone FC, Irving EA, Ray AM, et al. SB 239063, a secondgeneration p38 mitogen-activated protein kinase inhibitor, reduces brain injury and neurological deficits in cerebral focal ischemia. J Pharmacol Exp Ther 2001;296:312-321.

154. Alessandrini A, Namura S, Moskowitz MA, Bonventre JV. MEK1 protein kinase inhibition protects against damage resulting from focal cerebral ischemia. Proc Natl Acad Sci U S A 1999; 96:12866-12869.

155. Baeuerle PA, Henkel T. Function and activation of NF- $\kappa$ B in the immune system. Annu Rev Immunol 1994;12:141-179.

156. Schneider A, Martin-Villalba A, Weih F, Vogel J, Wirth T, Schwaninger M. NF- $\kappa$ B is activated and promotes cell death in focal cerebral ischemia. Nat Med 1999;5:554-559.

157. Herrmann O, Baumann B, de Lorenzi R, et al. IKK mediates ischemia-induced neuronal death. Nat Med 2005;11:1322-1329.

158. Ueno T, Sawa Y, Kitagawa-Sakakida S, et al. Nuclear factor- $\kappa$ B decoy attenuates neuronal damage after global brain ischemia: a future strategy for brain protection during circulatory arrest. J Thorac Cardiovasc Surg 2001;122:720-727.

159. Hill WD, Hess DC, Carroll JE, et al. The NF- $\kappa$ B inhibitor diethyldithiocarbamate (DDTC) increases brain cell death in a transient middle cerebral artery occlusion model of ischemia. Brain Res Bull 2001;55:375-386.

160. Mattson MP, Meffert MK. Roles for NF- $\kappa \mathrm{B}$ in nerve cell survival, plasticity, and disease. Cell Death Differ 2006;13:852-860.

161. Herdegen T, Waetzig V. AP-1 proteins in the adult brain: facts and fiction about effectors of neuroprotection and neurodegeneration. Oncogene 2001;20:2424-2437.

162. Chang LC, Tsao LT, Chang CS, et al. Inhibition of nitric oxide production by the carbazole compound LCY-2-CHO via blockade of activator protein-1 and CCAAT/enhancer-binding protein activation in microglia. Biochem Pharmacol 2008;76:507-519.

163. Jang S, Kelley KW, Johnson RW. Luteolin reduces IL-6 production in microglia by inhibiting JNK phosphorylation and activation of AP-1. Proc Natl Acad Sci U S A 2008;105:7534-7539.

164. Waetzig V, Czeloth K, Hidding U, et al. c-Jun N-terminal kinases (JNKs) mediate pro-inflammatory actions of microglia. Glia 2005;50:235-246.

165. Berger J, Moller DE. The mechanisms of action of PPARs. Annu Rev Med 2002;53:409-435.

166. Bernardo A, Minghetti L. Regulation of glial cell functions by PPAR- $\gamma$ natural and synthetic agonists. PPAR Res 2008;2008: 864140.

167. Braissant O, Foufelle F, Scotto C, Dauça M, Wahli W. Differential expression of peroxisome proliferator-activated receptors (PPARs): tissue distribution of PPAR- $\alpha,-\beta$, and $-\gamma$ in the adult rat. Endocrinology 1996;137:354-366.

168. Moreno S, Farioli-Vecchioli S, Cerù MP. Immunolocalization of peroxisome proliferator-activated receptors and retinoid $\mathrm{X}$ receptors in the adult rat CNS. Neuroscience 2004;123:131-145.

169. Bernardo A, Levi G, Minghetti L. Role of the peroxisome proliferator-activated receptor- $\gamma$ (PPAR- $\gamma$ ) and its natural ligand 15$\Delta^{12,14}$-prostaglandin $\mathrm{J}_{2}$ in the regulation of microglial functions. Eur J Neurosci 2000;12:2215-2223.

170. Luo Y, Yin W, Signore AP, et al. Neuroprotection against focal ischemic brain injury by the peroxisome proliferator-activated receptor- $\gamma$ agonist rosiglitazone. J Neurochem 2006;97:435-448.

171. Petrova TV, Akama KT, Van Eldik LJ. Cyclopentenone prostaglandins suppress activation of microglia: down-regulation of inducible nitric-oxide synthase by 15 -deoxy- $\Delta^{12,14}$-prostaglandin $\mathrm{J}_{2}$. Proc Natl Acad Sci U S A 1999;96:4668-4673.

172. Bernardo A, Ajmone-Cat MA, Levi G, Minghetti L. 15-deoxy$\Delta^{12,14}$-prostaglandin $\mathrm{J}_{2}$ regulates the functional state and the survival of microglial cells through multiple molecular mechanisms. J Neurochem 2003;87:742-751.

173. Straus DS, Pascual G, Li M, et al. 15-deoxy- $\Delta^{12,14}$-prostaglandin $\mathrm{J}_{2}$ inhibits multiple steps in the NF- $\kappa \mathrm{B}$ signaling pathway. Proc Natl Acad Sci U S A 2000;97:4844-4849. 
174. Victor NA, Wanderi EW, Gamboa J, et al. Altered PPAR $\gamma$ expression and activation after transient focal ischemia in rats. Eur J Neurosci 2006;24:1653-1663.

175. Ou Z, Zhao X, Labiche LA, et al. Neuronal expression of peroxisome proliferator-activated receptor- $\gamma$ (PPAR $\gamma$ ) and 15d-prostaglandin $\mathrm{J}_{2}$-mediated protection of brain after experimental cerebral ischemia in rat. Brain Res 2006;1096:196-203.

176. Culman J, Zhao Y, Gohlke P, Herdegen T. PPAR- $\gamma$ : therapeutic target for ischemic stroke. Trends Pharmacol Sci 2007;28:244249.

177. Sundararajan S, Gamboa JL, Victor NA, Wanderi EW, Lust WD, Landreth GE. Peroxisome proliferator-activated receptor- $\gamma$ ligands reduce inflammation and infarction size in transient focal ischemia. Neuroscience 2005;130:685-696.

178. Zhao Y, Patzer A, Gohlke P, Herdegen T, Culman J. The intracerebral application of the PPAR $\gamma$-ligand pioglitazone confers neuroprotection against focal ischaemia in the rat brain. Eur J Neurosci 2005;22:278-282.

179. Pereira MP, Hurtado O, Cárdenas A, et al. The nonthiazolidinedione PPAR $\gamma$ agonist L-796,449 is neuroprotective in experimental stroke. J Neuropathol Exp Neurol 2005;64:797-805.

180. Saijo K, Winner B, Carson CT, et al. A Nurr1/CoREST pathway in microglia and astrocytes protects dopaminergic neurons from inflammation-induced death. Cell 2009;137:47-59.

181. Yin F, Banerjee R, Thomas B, et al. Exaggerated inflammation, impaired host defense, and neuropathology in progranulin-deficient mice. J Exp Med 2010;207:117-128.

182. Saklatvala J. Glucocorticoids: do we know how they work? Arthritis Res 2002;4:146-150.

183. McRae A, Bona E, Hagberg H. Microglia-astrocyte interactions after cortisone treatment in a neonatal hypoxia-ischemia model. Brain Res Dev Brain Res 1996;94:44-51.

184. Li M, Wang Y, Guo R, Bai Y, Yu Z. Glucocorticoids impair microglia ability to induce $\mathrm{T}$ cell proliferation and Th1 polarization. Immunol Lett 2007;109:129-137.

185. Gomes JA, Stevens RD, Lewin JJ 3rd, Mirski MA, Bhardwaj A. Glucocorticoid therapy in neurologic critical care. Crit Care Med 2005;33:1214-1224.

186. Horner HC, Packan DR, Sapolsky RM. Glucocorticoids inhibit glucose transport in cultured hippocampal neurons and glia. Neuroendocrinology 1990;52:57-64.

187. Supko DE, Johnston MV. Dexamethasone potentiates NMDA receptor-mediated neuronal injury in the postnatal rat. Eur J Pharmacol 1994;270:105-113.

188. Qizilbash N, Lewington SL, Lopez-Arrieta JM. Corticosteroids for acute ischaemic stroke. Cochrane Database Syst Rev 2002; (2):CD000064.

189. Macario AJL, Conway de Macario EC. Molecular chaperones: multiple functions, pathologies, and potential applications. Front Biosci 2007;12:2588-2600.

190. Yenari MA, Liu J, Zheng Z, Vexler ZS, Lee JE, Giffard RG. Antiapoptotic and anti-inflammatory mechanisms of heat-shock protein protection. Ann N Y Acad Sci 2005;1053:74-83.

191. Ding XZ, Fernandez-Prada CM, Bhattacharjee AK, Hoover DL. Over-expression of hsp-70 inhibits bacterial lipopolysaccharideinduced production of cytokines in human monocyte-derived macrophages. Cytokine 2001;16:210-219.

192. Soriano MA, Planas AM, Rodriguez-Farre E, Ferrer I. Early $72-\mathrm{kDa}$ heat shock protein induction in microglial cells following focal ischemia in the rat brain. Neurosci Lett 1994;182:205-207.

193. Zheng Z, Kim JY, Ma H, Lee JE, Yenari MA. Anti-inflammatory effects of the $70 \mathrm{kDa}$ heat shock protein in experimental stroke. J Cereb Blood Flow Metab 2008;28:53-63.

194. Ran R, Lu A, Zhang L, et al. Hsp70 promotes TNF-mediated apoptosis by binding IKK $\gamma$ and impairing NF- $\kappa$ B survival signaling. Genes Dev 2004;18:1466-1481.

195. Feinstein DL, Galea E, Aquino DA, Li GC, Xu H, Reis DJ. Heat shock protein 70 suppresses astroglial-inducible nitric-oxide synthase expression by decreasing $\mathrm{NF} \kappa \mathrm{B}$ activation. J Biol Chem 1996;271:17724-17732.

196. Heneka MT, Sharp A, Klockgether T, Gavrilyuk V, Feinstein DL. The heat shock response inhibits NF- $\kappa \mathrm{B}$ activation, nitric oxide synthase type 2 expression, and macrophage/microglial activation in brain. J Cereb Blood Flow Metab 2000;20:800-811.

197. Yu YM, Kim JB, Lee KW, Kim SY, Han PL, Lee JK. Inhibition of the cerebral ischemic injury by ethyl pyruvate with a wide therapeutic window. Stroke 2005;36:2238-2243.

198. Yi JS, Kim TY, Kyu Kim D, Koh JY. Systemic pyruvate administration markedly reduces infarcts and motor deficits in rat models of transient and permanent focal cerebral ischemia. Neurobiol Dis 2007;26:94-104.

199. Lee JY, Kim YH, Koh JY. Protection by pyruvate against transient forebrain ischemia in rats. J Neurosci 2001;21:RC171.

200. Wang Q, van Hoecke M, Tang XN, et al. Pyruvate protects against experimental stroke via an anti-inflammatory mechanism. Neurobiol Dis 2009;36:223-231.

201. Han Y, Englert JA, Yang R, Delude RL, Fink MP. Ethyl pyruvate inhibits nuclear factor- $\kappa \mathrm{B}$-dependent signaling by directly targeting p65. J Pharmacol Exp Ther 2005;312:1097-1105.

202. Ulloa L, Ochani M, Yang H, et al. Ethyl pyruvate prevents lethality in mice with established lethal sepsis and systemic inflammation. Proc Natl Acad Sci U S A 2002;99:12351-12356.

203. Kim JB, Yu YM, Kim SW, Lee JK. Anti-inflammatory mechanism is involved in ethyl pyruvate-mediated efficacious neuroprotection in the postischemic brain. Brain Res 2005;1060:188192.

204. Yeung F, Hoberg JE, Ramsey CS, et al. Modulation of NF- $\kappa$ Bdependent transcription and cell survival by the SIRT1 deacetylase. EMBO J 2004;23:2369-2380.

205. Chen J, Zhou Y, Mueller-Steiner S, et al. SIRT1 protects against microglia-dependent amyloid- $\beta$ toxicity through inhibiting NF- $\kappa \mathrm{B}$ signaling. J Biol Chem 2005;280:40364-40374.

206. Nakamaru $Y$, Vuppusetty $C$, Wada $H$, et al. A protein deacetylase SIRT1 is a negative regulator of metalloproteinase-9. FASEB J 2009;23:2810-2819.

207. Shen Z, Ajmo JM, Rogers CQ, et al. Role of SIRT1 in regulation of LPS- or two ethanol metabolites-induced TNF- $\alpha$ production in cultured macrophage cell lines. Am J Physiol Gastrointest Liver Physiol 2009;296:G1047-G1053.

208. Liu D, Gharavi R, Pitta M, Gleichmann M, Mattson MP. Nicotinamide prevents $\mathrm{NAD}^{+}$depletion and protects neurons against excitotoxicity and cerebral ischemia: $\mathrm{NAD}^{+}$consumption by SIRT1 may endanger energetically compromised neurons. Neuromolecular Med 2009;11:28-42.

209. Baur JA, Sinclair DA. Therapeutic potential of resveratrol: the in vivo evidence. Nat Rev Drug Discov 2006;5:493-506.

210. Wang Q, Xu J, Rottinghaus GE, et al. Resveratrol protects against global cerebral ischemic injury in gerbils. Brain Res 2002;958: 439-447.

211. Della-Morte D, Dave KR, DeFazio RA, Bao YC, Raval AP, Perez-Pinzon MA. Resveratrol pretreatment protects rat brain from cerebral ischemic damage via a sirtuin 1-uncoupling protein 2 pathway. Neuroscience 2009;159:993-1002.

212. Kraus WL. Transcriptional control by PARP-1: chromatin modulation, enhancer-binding, coregulation, and insulation. Curr Opin Cell Biol 2008;20:294-302.

213. Ullrich O, Diestel A, Eyüpoglu IY, Nitsch R. Regulation of microglial expression of integrins by poly(ADP-ribose) polymerase-1. Nat Cell Biol 2001;3:1035-1042.

214. Kauppinen TM, Swanson RA. Poly(ADP-ribose) polymerase-1 promotes microglial activation, proliferation, and matrix metalloproteinase-9-mediated neuron death. J Immunol 2005;174:2288-2296.

215. Ha HC, Hester LD, Snyder SH. Poly(ADP-ribose) polymerase-1 dependence of stress-induced transcription factors and associated gene expression in glia. Proc Natl Acad Sci U S A 2002;99:32703275 .

216. Erdélyi K, Bakondi E, Gergely P, Szabó C, Virág L. Pathophysiologic role of oxidative stress-induced poly(ADP-ribose) polymerase-1 activation: focus on cell death and transcriptional regulation. Cell Mol Life Sci 2005;62:751-759.

217. Hassa PO, Hottiger MO. The functional role of poly(ADP-ribose) polymerase 1 as novel coactivator of NF- $\kappa \mathrm{B}$ in inflammatory disorders. Cell Mol Life Sci 2002;59:1534-1553.

218. Nakajima H, Nagaso H, Kakui N, Ishikawa M, Hiranuma T, Hoshiko S. Critical role of the auto-modification of poly(ADP- 
ribose) polymerase-1 in the nuclear factor- $\kappa \mathrm{B}$-dependent gene expression in primary cultured mouse glial cells. J Biol Chem 2004;279:42774-42786.

219. Chiarugi A, Moskowitz MA. Poly(ADP-ribose) polymerase-1 activity promotes NF- $\kappa \mathrm{B}$-driven transcription and microglial activation: implication for neurodegenerative disorders. J Neurochem 2003;85:306-317.

220. Phulwani NK, Kielian T. Poly (ADP-ribose) polymerases (PARPs) 1-3 regulate astrocyte activation. J Neurochem 2008; 106:578-590.

221. Love S. Oxidative stress in brain ischemia. Brain Pathol 1999;9: 119-131.

222. Couturier JY, Ding-Zhou L, Croci N, Plotkine M, Margaill I. 3-Aminobenzamide reduces brain infarction and neutrophil infiltration after transient focal cerebral ischemia in mice. Exp Neurol 2003;184:973-980.

223. Haddad M, Rhinn H, Bloquel C, et al. Anti-inflammatory effects of PJ34, a poly(ADP-ribose) polymerase inhibitor, in transient focal cerebral ischemia in mice. Br J Pharmacol 2006;149:23-30.

224. Eliasson MJ, Sampei K, Mandir AS, et al. Poly(ADP-ribose) polymerase gene disruption renders mice resistant to cerebral ischemia. Nat Med 1997;3:1089-1095.

225. Endres M, Wang ZQ, Namura S, Waeber C, Moskowitz MA. Ischemic brain injury is mediated by the activation of poly(ADPribose)polymerase. J Cereb Blood Flow Metab 1997;17:11431151.
226. Ding Y, Zhou Y, Lai Q, Li J, Gordon V, Diaz FG. Long-term neuroprotective effect of inhibiting poly(ADP-ribose) polymerase in rats with middle cerebral artery occlusion using a behavioral assessment. Brain Res 2001;915:210-217.

227. Kauppinen TM, Suh SW, Berman AE, Hamby AM, Swanson RA. Inhibition of poly(ADP-ribose) polymerase suppresses inflammation and promotes recovery after ischemic injury. J Cereb Blood Flow Metab 2009;29:820-829.

228. Yrjänheikki J, Keinänen R, Pellikka M, Hökfelt T, Koistinaho J. Tetracyclines inhibit microglial activation and are neuroprotective in global brain ischemia. Proc Natl Acad Sci U S A 1998; 95:15769-15774.

229. Yrjänheikki J, Tikka T, Keinänen R, Goldsteins G, Chan PH, Koistinaho J. A tetracycline derivative, minocycline, reduces inflammation and protects against focal cerebral ischemia with a wide therapeutic window. Proc Natl Acad Sci U S A 1999;96: 13496-13500.

230. Comen EA, Robson M. Inhibition of poly(ADP)-ribose polymerase as a therapeutic strategy for breast cancer. Oncology (Williston Park) 2010;24:55-62.

231. Switzer JA, Hall CE, Close B, et al. A telestroke network enhances recruitment into acute stroke clinical trials. Stroke 2010 41:566-569.

232. Lampl Y, Boaz M, Gilad R, et al. Minocycline treatment in acute stroke: an open-label, evaluator-blinded study. Neurology 2007; 69:1404-1410. 